\title{
Proporsi Seroproteksi Hepatitis B pada Usia 10-12 Tahun dengan Riwayat Imunisasi Dasar Hepatitis B Lengkap pada dua Sekolah Dasar di Jakarta
}

\author{
Suraiyah, Hanifah Oswari, Hardiono D Poesponegoro \\ Departemen Ilmu Kesehatan Anak, Fakultas Kedokteran Universitas Indonesia RS Dr. Cipto Mangunkusumo Jakarta
}

\begin{abstract}
Latar belakang. Hepatitis virus B merupakan penyakit yang tersebar di seluruh dunia dan menjadi masalah kesehatan yang serius dan mendesak. Indonesia termasuk daerah dengan endemisitas hepatitis B sedang sampai tinggi, maka sejak tahun 1996/1997 imunisasi hepatitis B di Indonesia telah mencakup 27 propinsi. Pemberian booster sampai saat ini masih kontroversi. Menurut WHO, seroproteksi hepatitis B bertahan paling sedikit 15 tahun, namun beberapa penelitian menunjukkan penurunan seroproteksi pada vaksin seiring dengan pertambahan waktu.

Metode. Studi deskriptif, potong lintang, pada anak kelompok usia 10-12 tahun pasca imunisasi dasar hepatitis B lengkap. Penelitian dilakukan pada bulan April-Juni 2007 di 2 SD Negeri di Jakarta.

Hasil. Dari 100 subjek yang diteliti didapatkan HBsAg negatif pada semua subjek. Usia rerata subjek 130 bulan (10 tahun 9 bulan), $S B=6,11$. Proporsi seroproteksi 38\%, rerata titer anti-HBs pada subjek seropositif $188,1 \mathrm{mIU} / \mathrm{mL}(\mathrm{SB}=97,6)$. Diantara semua subjek seropositif didapatkan $68,7 \%$ dengan respons rendah, 26,3\% dengan respons sedang, dan 5\% subjek dengan respons tinggi.

Kesimpulan. Proporsi seroproteksi anti-HBs pada usia 10-12 tahun pasca imunisasi dasar lengkap 38\%. Rerata titer anti-HBs pada 38 anak seropositif 188,1 mIU/mL (SB = 97,6). Di antara 38 subjek seropositif, sebagian besar mempunyai respons antibodi antihepatitis B rendah (Sari Pediatri 2008;9(6):423-8).
\end{abstract}

Kata kunci: vaksinasi hepatitis B, booster.

epatitis virus B (HVB) merupakan penyakit yang dijumpai tersebar di seluruh dunia. Infeksi virus hepatitis B pada usia dini mempunyai risiko tinggi

Alamat korespondensi

Dr. Hanifah Oswari, Sp.A(K), Departemen Ilmu Kesehatan Anak FKUI/ RSCM Jl. Salemba 6 Jakarta. Telp./fax. 021-3915712. E-mail: hanifah@idai.or.id terhadap kronisitas dan progresivitas penyakit. ${ }^{1}$ Seorang bayi yang terinfeksi virus hepatitis B sebelum usia 1 tahun, kemungkinan menderita kronisitas sekitar $90 \%$, apabila terjadi infeksi pada usia 1-5 tahun risikonya menurun menjadi $53 \%$, dan bila terinfeksi pada usia lebih dari 5 tahun hanya kurang dari $5 \% .^{2}$

Imunisasi merupakan cara untuk meningkatkan kekebalan seseorang secara aktif terhadap suatu antigen, sehingga bila kelak terpajan antigen serupa 
diharapkan tidak terjadi penyakit. Kekebalan aktif merupakan kekebalan yang dibuat oleh tubuh sendiri akibat terpajan antigen sebagai akibat pemberian imunisasi atau secara alami. ${ }^{3}$ Jadwal imunisasi hepatitis B rekomendasi Satgas Imunisasi PP IDAI adalah pertama diberikan pada usia kurang dari 12 jam, kedua usia 1 bulan dan ketiga usia 3 sampai 6 bulan. ${ }^{4}$ Lebih dari $95 \%$ anak yang mendapat imunisasi hepatitis B lengkap 3 kali (sesuai jadwal) akan mempunyai titer anti-HBs $\geq 10 \mathrm{mIU} / \mathrm{mL}$ (seropositif), yang berarti telah terbentuk kekebalan (seroproteksi) terhadap infeksi hepatitis B..$^{1,5,6}$

Penelitian prospektif di Taiwan terhadap 118 anak yang mendapat imunisasi dengan vaksin rekombinan dilakukan pemeriksaan anti-HBs segera setelah imunisasi hepatitis B dasar lengkap didapatkan seroproteksi hepatitis B 83-99\%, setelah 5 tahun proporsi seroproteksi $75-87 \%$ dan hanya $50-70 \%$ saat anak berusia 10-12 tahun. ${ }^{7}$ Penelitian prospektif lainnya pada 1200 anak usia 7 tahun dengan riwayat imunisasi hepatitis B dasar lengkap, didapatkan penurunan persentase seroproteksi dari $71,1 \%$ saat berusia 7 tahun menjadi $37,4 \%$ saat anak berusia 12 tahun. ${ }^{8}$

Penelitian jangka panjang (kohort) yang diikuti selama 15 tahun di Alaska pada 1578 anak yang telah mendapat imunisasi hepatitis $B$ terbukti terjadi penurunan rerata titer anti-HBs dari 822 IU/L pada 6 bulan pasca imunisasi ke-3 menjadi 27 IU/L setelah pemantauan 15 tahun. ${ }^{9}$ Peneliti lain mendapatkan 24 subjek terinfeksi hepatitis B pada akhir penelitian meskipun tanpa gejala klinis setelah pengamatan selama 14 tahun. $^{10}$

Pemberian booster saat ini tidak direkomendasikan, ${ }^{11}$ tetapi bila merujuk pada penelitian yang dilakukan di Taiwan dan Alaska maka pemberian booster perlu ditinjau kembali setelah pemantauan selama 10-15 tahun. ${ }^{7,8,10,12}$

\section{Metode}

Telah dilakukan studi deskriptif, potong lintang, untuk mengetahui proporsi seroproteksi hepatitis $\mathrm{B}$ dan rerata titer anti-HBs pada anak kelompok usia 10-12 tahun pasca imunisasi dasar hepatitis B lengkap. Penelitian dilakukan di dua sekolah dasar negeri (SDN) berdasarkan kriteria kelompok sosial menengah ke bawah SDN Pasar Manggis 01 Pagi dan SDN Gondangdia 01 Pagi (SD Argentina) mewakili kelompok sosial menengah ke atas. Waktu penelitian bulan April sampai Juni 2007.

Semua subjek penelitian telah mendapat imunisasi hepatitis B lengkap sebelum usia 18 bulan, menunjukkan hasil negatif pada pemeriksaan $\mathrm{HbsAg}$, dan orangtua menyetujui anaknya ikut serta dalam penelitian, dalam kondisi imunokompromais, menderita penyakit keganasan ataupun penyakit hati kronik, atau menderita kelainan hematologi yang memerlukan transfusi darah serial.

\section{Hasil}

Selama penelitian didapatkan 127 subjek yang bersedia turut serta dalam penelitian. Duapuluh tujuh subjek telah dapat ikut penelitian oleh karena usia di luar target (11), sudah mendapat booster (2), dan kelengkapan imunisasi hepatitis B saat bayi diragukan (14). Karakteristik subjek pada penelitian ini tertera pada Tabel 1.

Sebagian besar subjek penelitian adalah perempuan 66\%, 71\% mempunyai gizi baik dan 30\% masih memiliki buku imunisasi.

\section{Sebaran subjek berdasarkan seroproteksi}

Proporsi seroproteksi terhadap hepatitis B 38\%, rerata titer anti-HBs pada subjek yang seropositif $188,1 \mathrm{mIU} /$ $\mathrm{mL}(\mathrm{SB}=97,6)$, dan seronegatif didapatkan pada $62 \%$ subjek penelitian (Tabel 2).

\section{Sebaran titer anti-HBs berdasarkan kepemilikan data imunisasi}

Seropositif anti-HBs terdapat pada 38\% subjek, 18 diantaranya masih memiliki buku imunisasi. Gambar 1 menunjukkan titer anti-HBs 26 subjek dengan respons rendah, 10 respons sedang dan 2 respons tinggi. Untuk kepemilikan data imunisasi menunjukkan perbandingan hampir sama banyak antara subjek yang memiliki data imunisasi dibandingkan dengan yang tidak memiliki.

\section{Pembahasan}

Pemilihan subjek dimulai setelah mendapatkan izin dari kepala sekolah dan Kepala Dinas Pendidikan Dasar 
Tabel 1. Karakteristik subjek penelitian

\begin{tabular}{lcc}
\hline Karakteristik subjek & Jumlah & Persentase (\%) \\
\hline - Asal sekolah & & \\
SDN Pasar manggis 01 Pagi & 50 & 50 \\
SDN Gondangdia 01 Pagi (SD Argentina) & 50 & 50 \\
- Usia (tahun) & $10,9(6,11)$ & \\
Rerata (SB) & & \\
Jenis kelamin & 34 & 34 \\
Laki-laki & 66 & 66 \\
Perempuan & & \\
Kepemilikan data imunisasi (kartu/buku) & 30 & 30 \\
Ya & 70 & 70 \\
Tidak & & \\
Status gizi & 71 & 71 \\
Gizi baik & 29 & 29 \\
Gizi kurang & \\
\hline
\end{tabular}

Tabel 2. Sebaran subjek berdasarkan seroproteksi

\begin{tabular}{lccc}
\hline Seroproteksi & Anti-HBs $(\mathrm{mIU} / \mathrm{mL})^{*}$ & Jumlah & Persentase (\%) \\
\hline Tidak protektif (seronegatif) & $<10$ & 62 & 62 \\
. Protektif (seropositif) & $\geq 10$ & 38 & 38 \\
\hline Total & & 100 & 100 \\
\hline
\end{tabular}

* Keterangan: nilai proteksi anti-HBs $\geq 10 \mathrm{mIU} / \mathrm{mL}$

Provinsi DKI Jakarta, selanjutnya orangtua diminta untuk mengisi data anak dan menandatangani surat persetujuan penelitian apabila mengizinkan anaknya ikut serta dalam penelitian.

\section{Keterbatasan penelitian}

Keterbatasan penelitian ini antara lain, tidak semua subjek masih mempunyai buku catatan imunisasi, (30\%). Untuk mengurangi kesalahan data imunisasi, peneliti menanyakan kembali secara rinci mengenai frekuensi dan jadwal imunisasi, apakah imunisasi hepatitis B sudah lengkap sebelum usia 18 bulan. Peneliti juga menanyakan tempat dan atau siapa yang memberikan imunisasi untuk meyakinkan bahwa imunisasi benar sudah didapatkan subjek. ${ }^{13}$

\section{Karakteristik subjek penelitian}

Rentang usia 10-12 tahun dipilih karena dari beberapa penelitian dilaporkan bahwa pada usia 10-12 tahun titer anti-HBs sudah menurun sedangkan risiko terinfeksi hepatitis $\mathrm{B}$ tinggi.-10,12
Tingginya transmisi horisontal pada usia tersebut dapat karena adanya lesi kulit atau mukosa yang terpapar dengan darah atau cairan tubuh individu lain yang terinfeksi hepatitis B. Virus juga terdapat pada eksudat impetigo dan saliva meskipun dalam konsentrasi lebih sedikit dibandingkan dalam darah. Pemakaian handuk bersama yang terkontaminasi juga merupakan faktor risiko. ${ }^{14}$ Penelitian Akbar $\mathrm{N} \mathrm{dkk}$, menyatakan banyaknya jumlah anggota keluarga dalam satu rumah akan meningkatkan terjadinya transmisi hepatitis B. ${ }^{15}$

Data riwayat imunisasi merupakan informasi yang sangat penting, pada umumnya ditulis dalam kartu menuju sehat (KMS). Kartu KMS mudah robek, hilang, maupun tercecer, mengingat pentingnya data imunisasi maka beberapa tahun terakhir KMS diganti dengan buku imunisasi.

Pada buku imunisasi dituliskan berat badan, tinggi badan, tanggal, bulan dan tahun saat diberikan imunisasi, mencantumkan jenis vaksin, dosis, maupun tempat penyuntikkan. Pencatatan imunisasi penting karena data tersebut dapat dipakai sebagai catatan medis subjek, mengetahui kelengkapan imunisasi, 


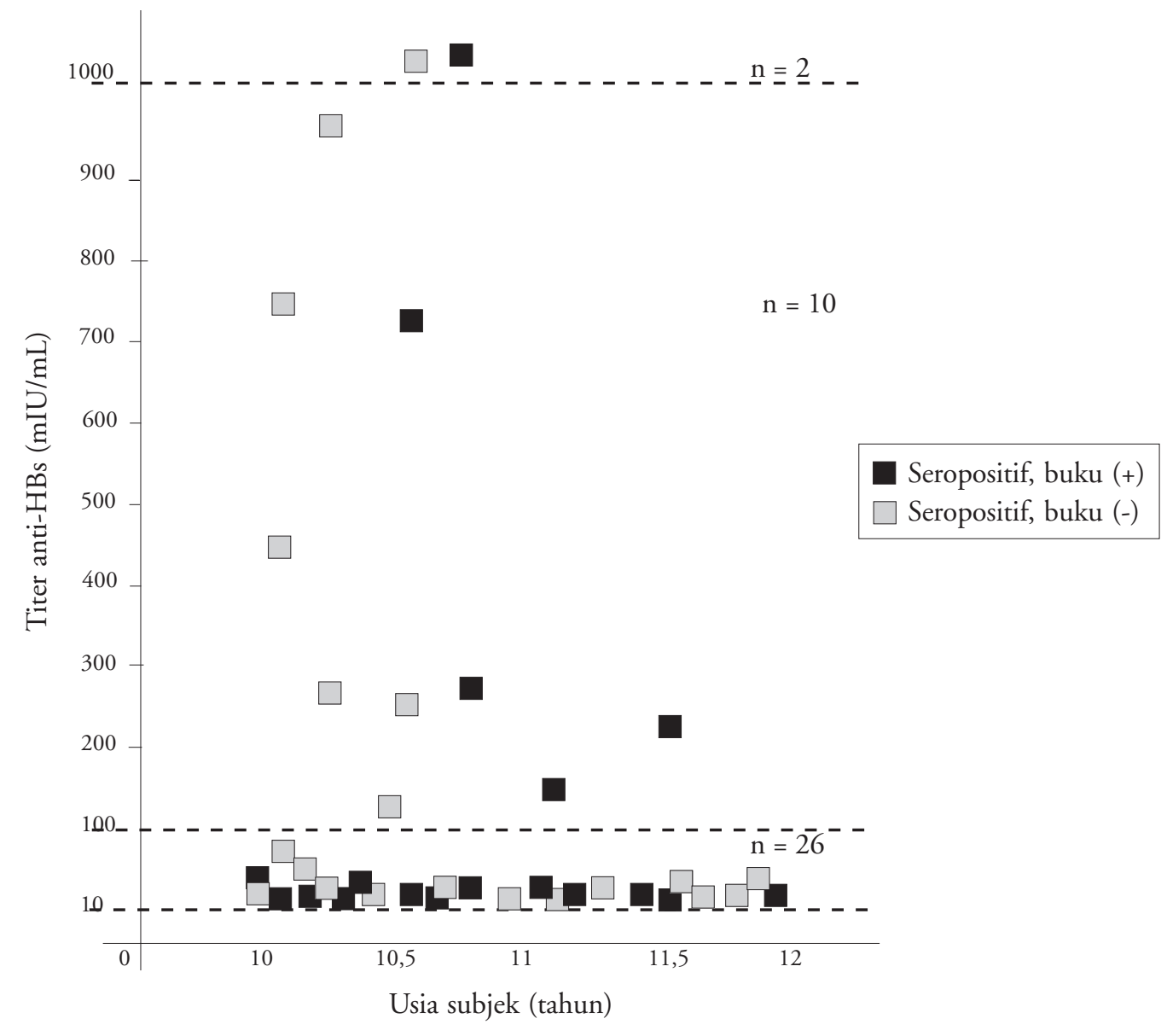

Gambar 1. Sebaran titer anti-HBs berdasarkan kepemilikan data imunisasi Keterangan: titer anti-HBs $10-100 \mathrm{mIU} / \mathrm{mL}=$ respon rendah $(26 \%), 100-1000 \mathrm{mIU} / \mathrm{mL}=$ respon sedang $(\mathrm{n}=10),>1000 \mathrm{mIU} /$ $\mathrm{mL}=$ respon tinggi $(\mathrm{n}=2)$

status nutrisi dan dapat mempermudah pengumpulan data bila dilakukan suatu penelitian. Tigapuluh delapan subjek seropositif, 18 diantaranya masih memiliki buku imunisasi. Namun masing-masing kelompok responder menunjukkan jumlah hampir sama banyak antara subjek yang memiliki data imunisasi dibandingkan dengan yang tidak memiliki data. ${ }^{12}$

Jadwal pemberian vaksinasi hepatitis B sebaiknya sedini mungkin karena infeksi hepatitis $\mathrm{B}$ pada usia dini lebih mempunyai risiko kronisitas dan progresifitas penyakit yang lebih tinggi. ${ }^{2}$ Jenis vaksin hepatitis B yang dipergunakan dalam penelitian adalah virus hepatitis dengan teknik rekombinan (vaksin rekombinan) yang beredar di Indonesia. Telah banyak laporan penelitian yang membandingkan efektifitas kelompok vaksin derivat plasma dan rekombinani. Kesimpulan dari suatu systematic review dan meta-analisis pada 29 uji klinis dengan randomisasi menunjukkan tidak didapatkan perbedaan bermakna antara jenis vaksin plasma derivat dibandingkan dengan vaksin rekombinan. ${ }^{16}$

\section{Uji serologis $\mathrm{HBsAg}$}

Uji serologis HBsAg menggunakan teknik Microparticle Enzyme immunoassay (MEIA) dengan AXSYMÒsystem HBsAg (V2), ABBOTT. Spesifisitas pemeriksaan MEIA 99,95-100\%. ${ }^{17}$ Semua subjek mempunyai uji serologi HbsAg negatif. Hasil penelitian ini hampir sama dengan penelitian di Taiwan yang menunjukkan persentase seroproteksi hepatitis B dari 1200 anak hanya 37,4\%, tetapi tidak didapatkan satupun subjek dengan HBsAg (+). Indonesia termasuk negara dengan endemisitas hepatitis B sedang sampai tinggi dengan prevalensi 
HBsAg (+) 2,4\%-9,1\% ${ }^{18}$, tidak ditemukan subjek dengan HBsAg $(+)$ pada penelitian ini merupakan bukti keberhasilan program imunisasi hepatitis B secara nasional sejak tahun 1997. Data dari Departemen Kesehatan Republik Indonesia mengenai cakupan imunisasi hepatitis B tahun 2000-2006 bervariasi. Wilayah Indonesia bagian Barat berkisar antara 43,9\%-100\%, sedangkan bagian Timur dengan angka cakupan yang lebih rendah yaitu 21,9\%-99,6\%. ${ }^{19}$ Sedangkan data WHO/ UNICEF (2004) menunjukkan presentasi cakupan nasional imunisasi hepatitis B di Indonesia terus meningkat $65 \%$ pada tahun 2000 menjadi $75 \%$ pada tahun 2004. ${ }^{20}$

Pembahasan hasil penelitian di Alaska menyatakan bahwa seseorang yang telah mendapat imunisasi hepatitis $\mathrm{B}$ namun titer anti-HBs $<10 \mathrm{mIU} / \mathrm{mL}$, tidak langsung kehilangan kemampuan proteksi karena secara in vitro masih ada memori imunologik, sehingga titer anti-HBs $<10 \mathrm{mIU} / \mathrm{mL}$ bukan menjadi dasar untuk pemberian booster. ${ }^{21}$ Pendapat lain mengatakan bahwa pemberian booster diperlukan untuk eradikasi infeksi hepatitis B karena hasil penelitian mereka menunjukkan 24 subjek yang terinfeksi meskipun telah mendapat imunisasi. ${ }^{22}$

\section{Seroproteksi}

Nilai titer anti-HBs dapat dideteksi berkisar antara 0 sampai $>1000 \mathrm{mIU} / \mathrm{mL}$. Titer anti-HBs seropositif didapatkan 38\%, hasil seropositif yang rendah ini menunjukkan bahwa proteksi pasca imunisasi hepatitis B tidak bertahan jangka panjang. Dari hasil yang ditemukan tidak dapat menjelaskan apakah pada subjek sudah terbentuk anti-HBs dan kemudian menurun atau sejak awal tidak terbentuk anti-HBs, karena subjek tidak mempunyai data awal. Efektifitas vaksinasi hepatitis B dalam pencegahan infeksi hepatitis B sangat baik, namun beberapa penelitian menunjukkan penurunan anti-HBs seiring dengan pertambahan waktu. Steering Committee for prevention at control of infections disease in Asia menganjurkan pemberian booster hepatitis B di daerah endemisitas tinggi, terutama di Asia. Panduan pemberian booster antara lain (1) pada anak usia 10-15 tahun, pasca imunisasi primer, (2) bila hasil titer antiHBs negatif, (3) pasien imunokompromais dengan anti$\mathrm{HBs}<10 \mathrm{mIU} / \mathrm{ml}$, (4) tenaga kesehatan yang bekerja di daerah endemis. ${ }^{23}$

\section{Kesimpulan}

Proporsi seroproteksi anti-HBs pada 100 anak usia 10 12 tahun pasca imunisasi dasar hepatitis B lengkap 38\%, dengan hasil seropositif $68,7 \%$ subjek respons rendah, $26,3 \%$ respons sedang, dan $5 \%$ respons tinggi. Nilai rerata titer anti-HBs pada 38 anak seropositif adalah 188,1 mIU/ $\mathrm{mL}(\mathrm{SB}=97,6)$. Perlu dipertimbangkan pemberian booster vaksinasi hepatitis B pada anak 10-12 tahun yang mempunyai titer anti $\mathrm{HBs}<10 \mathrm{mIU} / \mathrm{ml}$.

\section{Daftar Pustaka}

1. Balisteri WF, Yazigi NA. Acute and chronic viral hepatitis. Dalam: Suchy FJ, Sokol RJ, Balisteri WF, penyunting. Liver diseases in children. Edisi ke-2. St. louis: Mosby; 2001. h. 365-428.

2. MMWR. A comprehensive immunization strategy to eliminate transmission of hepatitis $\mathrm{B}$ virus infection in the United States 2005;54:RR-16.

3. Matondang CS, Notoatmojo H. Aspek imunologi imunisasi. Dalam: Akib Arwin AP, Matondang CS, penyunting. Buku ajar Alergi-imunologi anak. Edisi ke2. Jakarta; IDAI, 2007. h. 154-9.

4. Rezeki S, Soedjatmiko. Rekomendasi satgas imunisasi. Sari Pediatri; Jakarta: PP IDAI. 2006;8:84-7.

5. Mahoney FJ. Update on diagnosis, management, and preventing of hepatitis B virus infection. Clin Microbiol Rev 1999;12:351-66.

6. Aggarwal P, Ranjan P. Preventing and treating hepatitis B infection. Br Med J. 2004; 329:1080-6.

7. Huang LM, Chiang BL, Lee CY, Lee PI, Chi WK, Chang $\mathrm{MH}$. Long term rerponse to hepatitis $\mathrm{B}$ vaccination and response to booster in children born to mother with hepatitis B e antigen. Hepatology 1999;29:954-9.

8. Lin YC, Chang MH, Ni YH, Hsu HY, Chen DS. Longterm immunogenicity and efficacy of universal hepatitis virus vaccination in Taiwan. J Infect Dis 2003; 187:134-8.

9. Ni YH, Chang MH, Huang LM, Chen HL, Hsu HY, ChiuTY, et al . Hepatitis B virus infection in children and adolescents in a hyperendemic area: 15 years after mass hepatitis B vaccination. Ann Intern Med 2001; 135:796-800.

10. Whittle H, Jaffar S, Wansbrough M, Mendy M, Dumpis $\mathrm{U}$, et al. Observational study of vaccine efficacy 14 years after trial of hepatitis B vaccination in Gambian children. Br Med J 2002;325:569-74. 
11. WHO. Immunization schedule for infants recommended by the Expanded Programme on Immunization. Dalam: Pocket book of hospital care for children guidelines for the management of commont illness with limited resources. Switzerland: WHO Press 2005.

12. McMahon BJ, Burden DL, Peterson KM, Bulkow RL, Parkinson AS, et al. Antibody level and protection after hepatitis B vaccination: Result of a 15-year follow-up. Ann Intern Med 2005;142:333-41.

13. Suradi R, Siahaan CM, Boedjang RF, Soediyanto, Setyaningsih I, Soedibyo S, Penelitian kasus kontrol . Dalam: Sastroasmoro S, Ismael S, penyunting. Dasardasar metodologi penelitian klinis: Jakarta: Sagung Seto; 2002. h. 110-29.

14. Amstrong GL, Mast EE, Wojczynski, Margolis HS. Childhood hepatitis B virus infection in the United state before hepatitis B immunization. Pediatr 2001;108:11238.

15. Akbar N, Basuki B, Mulyanto, Garabrant DH, Noer HMS. Ethnicity, socioeconomic status, transfusions and risk of hepatitis B infection. J Gastrol Hepatol 1997; 12:52-7.

16. Lee C, Gong Y, Brok J, Boxall EH, Gluud C. Effect of hepatitis B immunization in newborn infants of mothers positive for hepatitis B surface antigen: Systematic review and meta-analysis. Diunduh dari: bmj.com pada tanggal 21 Agustus 2006.

17. ABBOTT. The ability of AXSYMÖHBsAg (V2) to detect $\mathrm{HBsAg}$ in specimens from blood donors, hospital patients and hepatitis B patients. ABBOT Diagnostics Division, Germany.

18. Sulaiman A, Julitasari. Epidemiologi hepatitis B. Dalam: Virus hepatitis A sampai E di Indonesia. Yayasan Penerbitan Ikatan dokter Indonesia.1995 h. 16-24.

19. Departemen Kesehatan Republik Indonesia. Data cakupan imunisasi nasional tahun 2000-2006.

20. UNICEF, WHO. A statistical reference data through 2004. Immunization Summary 2006.

21. Editorial: Long-term protection of hepatitis B vaccine:Lessons from Alaskan experience after 15 years. Ann Intern Med 2005;142:384-5.

22. Rathore MH. Hepatitis B vaccination provides protection for at least 15 years. AAP Grand Rounds 2005; 14:7-8

23. John TJ, Cooksley G; Steering committee for the prevention and control of infectious disease in Asia. Hepatitis $B$ vaccine boosters: is there a clinical need in high endemicity population?. J Gastroenterol Hepatol 2005;20:5-10. 